\title{
ЗОРОВЕ СПРИЙМАННЯ ТА ЙОГО ПОРУШЕННЯ В ДИТЯЧОМУ ВІЦІ
}

Вадим Кобильченко, Інститут спеціальної педагогіки і психології імені Миколи Ярмаченка Національної академії педагогічних наук України, м. Київ, Україна, vadimvk@ukr.net

Встановлено, що в процесі пізнання навколишнього світу найважливіша роль належить зору, а саме - зоровому сприйманню. Зір також $є$ засобом спілкування між дитиною й батьками, іншими дорослими і дітьми, спілкування з навколишнім світом. 3'ясовано, що відсутність зовнішніх впливів або ж їх істотне обмеження (сенсорна депривація), змінюе нормальне співвідношення біологічних, психологічних і соціальних чинників у психічному розвитку дітей. Доведено, що порушення зору в дитини можуть викликати значні утруднення в процесі їі розвитку, навчання й виховання. Обґрунтовано, що проблема пошуку оптимальних методів і засобів навчання та виховання дітей з аномаліями зору тісно пов'язана з розумінням психосрізіологічних механізмів, що лежать в основі відповідного десректу. Встановлено, що порушення зорового аналізатора і його провідних шляхів негативно позначається на формуванні у дитини психіки й складних психічних процесів, а згодом - і на розвитку особистості загалом.

Ключові слова: зір, зорові функції, зоровий аналізатор, зорове сприймання, порушення зору.

Вадим Кобыльченко, Институт специальной педагогики и психологии имени Николая Ярмаченко Национальной академии педагогических наук Украины, г. Киев, Украина Зрительное восприятие и его нарушения в детском возрасте

Установлено, что в процессе познания окружающего мира важнейшая роль принадлежит зрению, а именно - зрительному восприятию. Зрение также является средством общения между ребенком и родителями, другими взрослыми и детьми, общения с окружающим миром. Выяснено, что отсутствие внешних воздействий или их существенное ограничение (сенсорная депривация), изменяет нормальное соотношение биологических, психологических и социальных фракторов в психическом развитии детей. Доказано, что нарушение зрения у ребенка могут вызвать значительные затруднения в процессе его развития, обучения и воспитания. Обосновано, что проблема поиска оптимальных методов и средств обучения и воспитания детей с аномалиями зрения тесно связана с пониманием психофизиологических механизмов, лежащих в основе соответствующего десекта. Установлено, что нарушения зрительного анализатора и его проводящих путей негативно сказывается на фрормировании у ребенка психики и сложных психических процессов, а впоследствии - и на развитии личности в целом.

Ключевые слова: зрение, зрительные фрункции, зрительный анализатор, зрительное восприятие, нарушения зрения. 
Vadym Kobylchenko, Mykola Yarmachenko institute of special education and psychology of the national academy of educational sciences of Ukraine, Kyiv, Ukraine

Visual perception and visual perception disorders in children

It is established that in the process of perceiving the world, sight, namely visual perception plays the crucial role. Vision is also a way of communicating between the child and parents, other adults and children, communication with the outside world. It is found that the absence of external influences or their significant limitation (sensory deprivation), changes the normal ratio of biological, psychological and social factors in the mental development of children. It is proved that visual impairment in a child can cause considerable difficulties in the process of their development, education and upbringing. It is substantiated that the problem of finding optimal methods and means of teaching and educating children with visual impairments is closely related to understanding the psycho-physiological mechanisms underlying the defect. It is established that disorders of visual analyzer and its leading pathways adversely affects the formation of the child's psyche and complex mental processes, and subsequently - on the development of personality as a whole.

Keywords: vision, visual functions, visual analyzer, visual perception, visual impairment.

Постановка проблеми. У процесі пізнання навколишнього світу найважливіша роль належить зору, а саме - зоровому сприйманню. Зір також є засобом спілкування між дитиною й батьками, іншими дорослими і дітьми, спілкування з навколишнім середовищем.

Порушення зору в дитини можуть викликати значні труднощі в процесі їі розвитку, навчання й виховання. Тому, набуває значення теоретичний огляд та аналіз зорового сприймання в нормі та при певних його порушеннях в дитячому віці.

Виклад основного матеріалу дослідження. Отже, різноманітну інформацію про навколишній світ дитина отримує завдяки наявності зору. Зір забезпечується функцією зорового аналізатора, який є складною системою, що охоплює три відділи: очне яблуко (саме око), яке сприймає зорове подразнення й перетворює його у нервове збудження; зорові шляхи, по яких нервове збудження передається у головний мозок; потиличні долі кори головного мозку, де формується зоровий образ.

Так, дитина сприймає навколишній світ за допомогою очей. Від них інформація певними шляхами передається у певні ділянки потиличних частин кори головного мозку, де й формується та картина зовнішнього світу, яку ми бачимо. Усі ці органи й складають зоровий аналізатор або зорову систему.

Як зазначалося вище, дитина використовує зір з практичною метою. Зорова поведінка дитини свідчить про іiі загальні зорові можливості та є результатом взаємодії кількох різних зорових функцій, зокрема таких: центральний зір, периферичний зір, кольоровий зір, сутінковий зір, бінокулярний зір. Тепер коротко ї охарактеризуємо.

Центральний (або предметний зір) - забезпечує чітке бачення предметів довкілля, їх розмірів та форм. Центральний зір вимірюється гостротою зору, яка

«ОСОБЛИВА ДИТИНА: навчання і виховання», № 4, 2019 
залежить від мінімальної відстані між двома точками, які око здатне сприймати роздільно.

Периферичний зір - це сприймання частини простору навколо фіксованої точки. Він дає можливість орієнтуватись у просторі. Простір, який сприймається одним оком, називається полем зору - це все поле, яке бачить око одночасно при нерухомому положенні голови й погляду.

При різних хворобах ока поля зору можуть звужуватись чи випадати ї окремі ділянки. Якщо поле зору дуже вузьке, стає важко або й зовсім неможливо орієнтуватися у просторі.

Може бути, що центральний зір є збереженим, а поле зору вузьким. Дитина з таким полем зору спроможна читати, однак не може самостійно орієнтуватись у просторі. I навпаки, якщо периферичний зір є збереженим, а центральний зір різко зниженим, то дитина не може читати, нечітко бачить предмети, проте пересувається самостійно.

Кольоровий зір дає змогу сприймати до 160 відтінків різних кольорів, завдяки чому дитина сприймає всю красу навколишнього світу. Око налаштовано на сприймання трьох основних кольорів спектру: червоного, зеленого й синього. При недостатньому сприйманні одного з трьох основних кольорів виникає аномалія кольору. А якщо око не сприймає усі три основні кольори, з'являється кольорова сліпота - ахроматичний зір.

Світловідиуття (сутінковий зір) - це здатність сприймати світло та пристосовуватися до сприймання зорових образів при різних рівнях освітленості, зокрема в сутінках, коли ми нечітко розрізняємо кольори. Порушення сутінкового зору може бути вродженим результатом авітамінозу або захворювання.

Бінокулярний зір - це бачення обома очима. Ця зорова функція забезпечує глибинне, рельєфне, просторове, стереоскопічне сприймання навколишнього світу.

Порушення зору у дитини можуть викликати значні утруднення в процеci iii розвитку, навчання й виховання. Вони зумовлюються різними причинами. Ушкодження органу зору у дитини можуть бути вродженими (наприклад, деякі форми вродженої катаракти), внутрішньоутробними патологіями зорового органу внаслідок токсоплазмозу, краснухи та інших тяжких захворювань матері під час вагітності, особливо на ранніх їі етапах, коли у плода формуються органи зору. Зорова патологія може бути наслідком захворювань самої дитини, наприклад, менінгітом, менінгоенцефалітом, при пухлинах мозку тощо.

Причинами вроджених порушень є ушкодження або захворювання плоду під час вагітності, або можуть бути наслідком спадкової передачі деяких порушень зору.

Набуті порушення зору можуть з'явитися внаслідок захворювань органів зору - сітківки, рогівки, а також захворювань центральної нервової системи, про які згадувалось вище, та ускладнень після загальних захворювань організму дитини (кір, грип, скарлатина), травматичних ушкоджень мозку (поранення голови, від удару) та очей.

Розрізняють прогресуючі та не прогресуючі порушення зорового аналізатора. При прогресуючих зорових порушеннях відбувається погіршення зорових функ- 
цій під впливом патологічного процесу. Наприклад, зір знижується при прогресуючих пухлинах мозку, при недотриманні санітарно-гігієнічних умов письма й читання (прогресуюча короткозорість і далекозорість). До не прогресуючих порушень зорового аналізатора відносять деякі вроджені його вади (астигматизм, катаракта). Їх причинами можуть бути й наслідки деяких захворювань організму дитини, очей і очних операцій.

Найбільш розповсюдженою групою зорових розладів є порушення рефракції зору, або розлади зору, при яких відбувається розфокусування зображення на сітківці. До них відносять три варіанти порушення рефракції: далекозорість, короткозорість та астигматизм. Серед найбільш розповсюджених порушень зору називають також косоокість, яка виникає через захворювання м'язів ока, зорового нерва і зорових шляхів.

Далекозорість (гіперметропія) - це патологія рефракції ока при якій зображення предметів формується за сітківкою. Розрізняють: слабку гіперметропію до +2 діоптрій; середню гіперметропію - до +5 діоптрій; сильну гіперметропію - вище +5 діоптрій.

При слабкому ступені далекозорості зір удалину є гарним, але можуть бути скарги на швидку стомлюваність, головний біль при значних зорових навантаженнях. При середньому ступені далекозорості - зір удалину залишається гарним, а поблизу - ні. За високої гіперметропії - зір є поганим і удалину, i поблизу, тому що вичерпані всі можливості ока, фокусувати на сітківці зображення, навіть далеко розташованих предметів.

Далекозорість - підступне захворювання. Перші симптоми з'являються в дитинстві: діти погано вчаться, швидко стомлюються, не можуть зосередитись на виконанні завдання, вередують, погано сплять. Перевтома зорового апарата при далекозорості передусім проявляється саме астенічними скаргами. Прогресування далекозорості може привести до порушень відтоку внутрішньоочної рідини i, як наслідок, підйому внутрішнього очного тиску й розвитку глаукоми.

Рання діагностика й призначення оптичної корекції (окуляри, контактні лінзи) дає можливість скоротити виникнення таких ускладнень гіперметропії, як косоокість й амбліопія (синдром ледачого ока).

Косоокість є відхиленням однієї із зорових осей від сумісної точки фіксації погляду при відсутності бінокулярного зору. Порушення бінокулярного зору при косоокості спостерігається у більшості дітей. Встановлено, що косоокістю страждають від 1,5 до 2 \% дітей. Іноді важко визначити, має дитина косоокість чи не має, особливо у випадку, коли у дитини широке перенісся.

Амбліопія - це зниження гостроти зору, яке не коригується оптично. Вона розвивається внаслідок ранньої сенсорної депривації. За ступенем зниження зору розрізняють високу амбліопію (гострота зору від 0,001 до 0,1), середню $(0,1-$ $0,3)$ й слабку $(0,3-0,8)$. Амбліопія виникає через вроджену або ранню катаракту, вроджену аномалію рефракції, косоокість.

Короткозорість (міопія) - це часта патологія рефракції ока при якій зображення предметів формується перед сітківкою. У людей з короткозорістю або збільшена довжина ока - осьова короткозорість, або рогівка має більшу залом-

«ОСОБЛИВА ДИТИНА: навчання і виховання», № 4, 2019 
люючу силу, через що виникає невелика фокусна відстань - рефракційна короткозорість.

Зазвичай, буває сполучення цих двох моментів. Короткозорі люди добре бачать поблизу й погано вдалині. При короткозорості віддалені предмети здаються розпливчастими, змазаними, нерізкими. Гострота зору стає нижчою за 1,0. Залежно від ступеня зниження гостроти зору розрізняють: слабку міопію - до 3 діоптрій; середню міопію - до 6 діоптрій; сильну міопію - вище 6 діоптрій.

Короткозорість (міопія) може мати спадковий та набутий характер. Спадковість виявляється тоді, коли батьки короткозорі: у половини дітей короткозорість з'являється ще до початку навчання в школі. 3-поміж зовнішніх причин є перенапруга очей - тривалі й інтенсивні зорові навантаження на близькій відстані, погане освітлення, неправильна посадка при читанні й письмі, надмірне захоплення телевізором і комп'ютером. Здебільшого, поява короткозорості збігається за строками із початком шкільного навчання або зумовлена інтенсивною підготовкою дитини до школи у дошкільному віці.

Астигматизм - це патологія рефракції ока, при якій порушується сферичність рогівки, тобто в різних меридіанах різна заломлююча сила й зображення предмета при проходженні світлових променів через таку рогівку виходить не у вигляді крапки, а у вигляді відрізка прямої лінії. Людина при цьому бачить предмети перекрученими, у яких одні лінії чіткі, а інші є розмитими. Зображення предметів при астигматизмі нечітке, місцями розмите, прямі лінії виглядають вигнутими. Крім дефектів зорового сприймання, астигматизм зазвичай супроводжується швидкою стомлюваністю очей, зниженням зору, головними болями.

Вроджений астигматизм до 0,5 діоптрій зустрічається у більшості людей і належить до «функціонального», що практично не впливає на гостроту зору. Однак, як свідчить практика, астигматизм вже в 1 діоптрію й більше знижує зір і погіршує зоровий комфорт. Отже, у більшості випадків астигматизм має вроджений і спадковий характер та виявляється вже в дитячому віці. Однак причиною астигматизму можуть бути також очні травми.

Хвороба кришталика (катаракта), глаукома та інші тяжкі захворювання судинної оболонки і сітківки можуть призвести до повної втрати зору - сліпоти.

Традиційне визначення поняття глаукоми полягає у тім, що цей термін поєднує велику групу захворювань ока, що характеризується постійним або періодичним підвищенням внутрішнього очного тиску, через порушення відтоку рідини з ока. Наслідком підвищення тиску є розвиток характерних для глаукоми порушень зорових функцій й атрофії зорового нерва.

3-поміж видів глаукоми виділяють вроджену й придбану глаукому. Вроджена глаукома зустрічається не так часто й лікування (хірургічне) проводять у дитячих відділеннях лікарень у ранньому віці. У придбаних глаукомах виділяють вікову первинну та вторинну глаукому, що пов'язана із травмами ока та захворюваннями ока або організму загалом. За віком дитини глаукому класифікують як вроджену (проявляється до 3 років) та інфантильну (від 3 до 10 років).

Проблема пошуку оптимальних методів і засобів навчання та виховання дітей з аномаліями зору тісно пов'язана з розумінням психофізіологічних меха- 
нізмів, що лежать в основі відповідного дефекту. Як встановлено рядом фундаментальних досліджень у царині психології та тифлології, порушення зорового аналізатора і його провідних шляхів негативно позначається на формуванні у дитини психіки й складних психічних процесів, а згодом - i на розвитку особистості загалом.

Відсутність зовнішніх упливів або ж їх істотне обмеження (сенсорна депривація), на думку деяких авторів [4], змінює нормальне співвідношення біологічних, психологічних і соціальних чинників у психічному розвитку дітей. Передусім порушується морфофункціональне визрівання центральної нервової системи в умовах сенсорної депривації, яку можна розглядати як дефіцит активації мозку.

Відомо, що вищі психічні функції виникають на основі відносно елементарних сенсорних і моторних процесів. На ранніх етапах розвитку цей зв'язок вищих психічних процесів з їх чуттєвою (сенсорною та моторною) основою виступає особливо чітко, але при подальшому їхньому розвитку ці чуттєві компоненти поступово згортаються, продовжуючи, однак, входити в них як компоненти [9].

До сказаного варто додати, що вищі психічні функції можуть існувати тільки завдяки взаємодії високодиференційованих мозкових структур, кожна з яких вносить свій специфічний вклад у динамічне ціле і бере участь у функціональній системі, виконуючи свою специфічну роль.

Вроджені та набуті дефекти зору (захворювання сітківки, зорового нерва, ураження зорових зон мозку тощо) відносять до первинних соматичних дефектів. Ці аномалії викликають вторинні функціональні відхилення (зниження гостроти зору, звуження або випадіння частин поля зору, порушення відчуття світла й кольору), що негативно впливають на розвиток багатьох психічних процесів (відчуття, сприймання, уявлення тощо) [8].

Як зазначав I. Моргуліс [10], через зоровий дефект та його безпосередні наслідки у подальшому страждають вищі психічні функції, які надбудовуються над елементарними. Тобто, вторинні відхилення породжують нові відхилення у психічному розвитку дитини.

Так, вторинні дефекти являють собою довгий ланцюг відхилень, у якому один функціональний дефект (наприклад, зниження гостроти зору) тягне за собою інший (відхилення у процесі сприймання). Звідси випливає, що між соматичним дефектом і аномаліями в розвитку психіки є складні структурні та функціональні зв'язки: відхилення не тільки утворюють довгі ланцюги психічних дефектів, що послідовно виникають, але і взаємодіють між собою [8].

Як стверджував О. Лурія, для порушення функції буває достатньо, щоб випала будь-яка ланка складної функціональної системи. Іншими словами, втративши будь-яку необхідну для виконання функції ланку, функціональна система загалом або розпадається, або перебудовується, щоб виконувати потрібну функцію новим набором засобів.

Вищі психічні функції справді можуть страждати при ураженнях найрізноманітніших ланок функціональної системи, однак при ураженні різноманітних ланок вони страждають по-різному.

«ОСОБЛИВА ДИТИНА: навчання і виховання», № 4, 2019 
Первинним у кожному випадку виступає порушення власної функції ураженої ділянки, яка забезпечує нормальну роботу певної ланки функціональної системи. Вторинним (або системним) наслідком цього порушення є розпад усієї функціональної системи в цілому. Нарешті можна виділити й ті функціональні перебудови, що відбуваються в патологічно зміненій системі, і що призводять до компенсації дефекту завдяки залученню збережених ланок кіркового апарату [9].

Будь-який дефект, тобто фізичний або психічний недолік, наслідком якого $є$ порушення нормального розвитку, неминуче призводить до автоматичного залучення біологічних компенсаторних функцій організму. В цьому сенсі компенсацію можна визначити як універсальну спроможність організму тією чи тією мірою відшкодовувати порушення або втрату певних функцій $[8,13]$.

Фізіологічний механізм компенсації грунтується на нормальному функціонуванні збережених систем. Сучасні наукові дослідження свідчать, що робота фізіологічного механізму компенсації порушених функцій підкоряється загальним закономірностям вищої нервової діяльності, бо його субстратом є центральна нервова система. В основі компенсації лежить рефлекторна діяльність організму. При цьому залучення механізмів компенсації відбувається безумовно-рефлекторним шляхом, автоматично, а подальший розвиток компенсаторних пристосувань є наслідком умовно-рефлекторної діяльності $[8,13]$.

Дослідження вищої нервової діяльності показали, що випадіння або глибокі порушення функцій зорового аналізатора впливають на умови, у яких протікає діяльність організму, і викликають серйозні зміни у внутрішніх центральних зв'язках. Ці зміни призводять до деякого підсилення гальмівного процесу. Його домінування виявляється у зниженні швидкості виникнення умовних рефлексів, уповільненні вироблення диференціювань й переробки сигнальних значень умовних подразників на протилежні.

Надзвичайно суттєвим негативним моментом є різке скорочення обсягу інформації, що спостерігається при слабозорості. Це пов'язано не тільки і не стільки з порушенням зорових функцій, скільки з перцептивними можливостями збережених аналізаторних систем. Навіть така система, як тактильно-кінестетична, значно поступається зоровій системі.

Звуження поля сприймання спостерігається не тільки при тотальній, й при парціальній сліпоті та слабозорості. Поряд із вкрай обмеженими можливостями одночасного охоплення простору за допомогою дотику, в останньому випадку різко звужується поле зорового сприймання. Усе це - і обмеженість поля сприймання, і зниження пропускної спроможності аналізаторних систем у сліпих та слабозорих, призводить у кінцевому результаті до скорочення впливу «нових» подразників, які є необхідними для задоволення перцептивної потреби, розвитку пізнавального інтересу, формування активності суб'єкта пізнання [8, 13].

Отже, порушення у слабозорих дітей діяльності зорового аналізатора призводить до перебудови усіх зв'язків між аналізаторами, утворення нових внутрішніх або міжаналізаторних зв'язків [8].

Хоча слабозорість не змінює структури чуттєвого пізнання, окремі його компоненти - відчуття, сприймання й уявлення - як якісно, так і кількісно 
відрізняються від означених процесів у дітей з нормальним зором. Насамперед, ці зміни виявляються у сфері відчуттів, що пояснюється їннім місцем та роллю в процесі пізнання.

Порушення функцій зорового аналізатора призводить до того, що, з одного боку, у слабозорих дітей або випадають повністю, або послаблюються, редукуються зорові відчуття, а з іншого - відчуття інших модальностей отримують у процесі діяльності компенсаторну гіперфункцію. Зміни у сфері відчуттів (на першій сходинці чуттєвого пізнання) неминуче мають позначитись на наступному його етапі - сприйманні $[8,13,14]$.

Проблема сприймання - є однією із центральних проблем сучасної експериментальної психології. В останній час дослідники почали розглядати сприймання людини як активний процес, що охоплює, крім сенсорних систем, і моторні ланцюжки, передусім, - діментарні компоненти обмацування та пошукові рухи очей. Найбільш складні форми сприймання стали розглядатися як процес, до якого входять елементи кодування, що відбувається за активною участю мовлення [7].

Відомий фізіолог I. Сечєнов [12] у своїх працях вказував, що кожний акт зорового сприймання охоплює поряд 3 аферентними ще й еферентні механізми. Око, сприймаючи предмети навколишнього світу, активно їх «обмацує», і ці рухи, поряд з пропріоцептивними сигналами від м'язів ока, входять як елементи до складу зорового сприймання.

Так, для здійснення функції зорово-просторового сприймання необхідним є збережене функціонування зорової системи й достатньо повне функціонування окорухового апарату. Така сенсомоторна координація забезпечує точну експозицію сітківки на об'єктах просторового поля, що є необхідним для точного скеровування та переведення погляду таким чином, щоб центральна частина сітківки фіксувалася на сприйнятих об'єктах.

Рухи очей є одним із індикаторів діяльності не тільки сприймання, а й мислення. Існують дві форми рухів очей: фазичні (погляд у різні сторони) i тонічні (фіксація погляду). У процесі сприймання 95-97 \% усього часу розглядання займає фіксація, а попередні фазичні рухи очей готують передумови для цієї роботи.

Сприймання - це складний синтетичний процес, у якому беруть участь декілька аналізаторів. Під час виконання різноманітних видів діяльності, один з аналізаторів стає провідним, домінуючим, залежно від умов життя й характеру самої діяльності. Згідно з цим, визначається притаманний тій або іншій людині тип сприймання. У нормі, у більшості людей, формується зоровий тип сприймання. Характерним є те, що навіть такі серйозні порушення функцій зору, які спостерігаються у дітей із залишковим зором та слабозорих, не викликають зміни типу сприймання.

Тільки при найбільш значних зниженнях гостроти зору (від 0,03-0,02 і нижче) та при тотальній сліпоті, коли більша частина предметів і явищ навколишньої дійсності не може бути адекватно сприйнята візуально, домінуюче положення займають шкіряно-механічний і руховий аналізатори, що лежать в основі

«ОСОБЛИВА ДИТИНА: навчання і виховання», № 4, 2019 53 
дотикового сприймання. Проте, зоровий аналізатор, залежно від рівня гостроти зору й характеру діяльності, продовжує у тій чи іншій мірі брати участь у процесі сприймання. А у деяких видах діяльності, при орієнтуванні у великому просторі, аномальний зір навіть при дуже низькій його гостроті може займати провідні позиції $[8,14]$.

Кінцевим результатом процесу зорового сприймання є утворення образу. Предметність перцепції визначає відображення цілісності об'єкта, його структури, що свідчить про свідомість сприймання. Зорові образи, як і будь-які психічні образи, багатомірні, складні й обов'язково охоплюють три рівня відображення: сенсорно-перцептивний, рівень уявлень і вербально-логічний. Вони відіграють важливу роль у розвитку пізнавальних процесів, емоційної сфери, у формуванні багатьох умінь і навичок. У дітей із порушеннями зору формуються збіднені, часто деформовані та нестійкі зорові образи. Для них є характерними ригідність і малорухомість, стереотипність. Порушення зору, зазвичай впливає на протікання усього процесу формування образів. Так, для зорового сприймання, як і для перцепції будь-якої модальності, властиві вибірковість тобто виділення тих об'єктів, які перебувають у сфері інтересів, діяльності та уваги дитини. При слабозорості, послаблюється інтерес до навколишнього, знижується загальна активність i, як результат, - спостерігається вибірковість перцепції [14].

Результати вивчення процесу формування зорових образів у слабозорих дітей свідчать про їню залежність від ступеня та характеру порушення зору. У них спостерігається не сформованість антиципації, низький рівень виділення ознак об'єктів, їхньої інтеграції й порушення механізмів їхнього формування [14]. Водночас, порушується симультанність сприймання ознак, збільшується кількість послідовних, і знижується кількість паралельних операцій. Процес стає розгорнутим і тривалим, що викликає утруднення інтеграції образа об'єкта через погіршення розрізнення й порушення одночасності розпізнавання ознак.

Сприймання дітьми з порушеннями зору складних кольорових зображень сюжетних ситуацій та пейзажів, а також упізнавання зображень на основі сприйняття окремих його частин характеризується нестабільністю, неповнотою образів, низьким рівнем вербалізації, слабким розвитком візуального мислення, що свідчить про труднощі об'єднання сенсорної й несенсорної інформації, наслідком чого є збіднений запас уявлень, формалізм мовлення. Усе це утруднює загалом розуміння дітьми сюжету малюнка, виділення його змісту й виявлення причинно-наслідкових зв’язків. Ці факти показують також слабкість формування механізму антиципації - випереджального відображення.

Збіднення інформації внаслідок патології зорової системи у слабозорих обумовлює появу такої особливості їхнього перцепції, як схематизм зорового образа, його збіднення. Порушується цілісність сприймання об'єкта, в образі об'єкта часто є відсутніми не тільки другорядні, а й визначальні деталі, що призводить до фрагментарності та неточності уявлень про навколишній світ. Порушення цілісності зумовлюе труднощі формування структури образу, ієрархії ознак об'єкта. 
Для нормального функціонування зорового сприймання характерною $€$ константність, тобто - здатність розпізнавати об'єкт поза залежністю від його положення, відстані від очей, освітленості, тобто - від умов сприймання. Для слабозорих зона константного сприйняття звужується залежно від ступеня ураження зору.

Важливою властивістю перцепції є узагальненість сприймання, тобто вміння абстрагуватись від випадкових, несуттєвих ознак об'єкта, виділення істотних його якостей та віднесення до певного класу об'єктів. Ця властивість виступає у єдності із розумовими операціями аналізу, синтезу, порівняння та узагальнення. Труднощі виділення істотних якостей, відсутність цілісності зорового образу, його фрагментарність і неповнота визначають низький рівень узагальненості образів при глибоких порушеннях зору. Так, відсутність у системі полісенсорного відображення зовнішнього світу зорових образів або їх бідність, неточність, нечіткість, недостатня цілісність, зазвичай, позначаються на характері уявлень про навколишній світ слабозорих дітей. Оскільки кожен аналізатор, входячи в сенсорну систему, несе на собі вплив діяльності усієї системи, то порушення зору змінює їхню взаємодію й міжаналізаторні зв'язки [3].

При слабозорості, у порівнянні з нормою, процес утворення образу змінюється: порушується симультанність упізнання ознак форми, розміру та кольорів. Особливо це спостерігається при органічних порушеннях зорового аналізатора. Різні за ступенем порушення сенсорних механізмів, що аналізують кольори й форму, викликають дисоціацію іхнього функціонування. У результаті, знижується здатність паралельної оцінки різних ознак одного об'єкта. Зазвичай, упізнання об'єктів передбачає опис і зберігання іх в образній (іконічній) пам'яті. У слабозорих спостерігається звуження середнього обсягу іконічної пам'яті [4].

Найбілыші порушення іконічної пам'яті спостерігаються також при ускладнених захворюваннях ока, зокрема сітківки, атрофії зорових нервів. Упізнання залежить також від інформаційного обсягу перцептивного поля: його перевантаження утруднює впізнання навіть при збільшенні часу розглядання.

Варто зауважити, що зорове сприймання є провідним при соціальній перцепції, яку психологічна наука трактує як сприймання людьми соціальних об’єктів (інших людей, самих себе, соціальних груп тощо). Термін «соціальна перцепція» запровадив американський психолог Дж. Брунер [2] для позначення факту соціальної детермінованості сприймання, його залежності не тільки від характеристик стимулу - об'єкта, а й від попереднього досвіду суб'єкта, його цілей, намірів та значущості ситуації.

Однією із важливих внутрішніх детермінант соціальної перцепції є соціальна установка індивіда, яка забезпечує стабільність, послідовність, інтенціональність психічної діяльності. У разі, якщо існуюча установка суперечить наявній ситуації, є «застарілою», консервативною, вона може зумовлювати інертність та дезадаптацію індивіда.

Б. Ананьєв [1] у сенсорно-перцептивній організації людини виділяє три рівні: функціональний, операційний та, пов'язаний із двома першими, - мотиваційний. Відомо, що сприймання соціальних об’єктів охоплює певні специфічні

«ОСОБЛИВА ДИТИНА: навчання і виховання», № 4, 2019 55 
риси, які якісно відрізняють його від звичайного сприймання предметів. Передусім, соціальний об'єкт (індивід, група) не є пасивним і байдужим щодо суб'єкта. По-друге, сприймання соціальних об'єктів характеризується повнішою злитістю когнітивних компонентів із емоційними, більшою залежністю від мотиваційносмислової структури діяльності суб'єкта.

У структурі будь-якого перцептивного досвіду виділяються суб'єкт і об'єкт сприймання, його процес і результат (утворення образу). Образ іншої людини або власний Я-образ і є важливим продуктом соціальної перцепції, який залучений у процес соціальної взаємодії.

Саме тому, суттєві зміни в структурі чи протіканні перцептивного акту внаслідок випадіння або редукованості зорового сприймання неодмінно негативно позначається на його результаті.

Порівняльне дослідження сприймання, розуміння й оцінки емоційних станів дітьми дошкільного віку з амбліопією й косоокістю, проведене Л. Григор'євою показало їхню значну відмінність від дітей із нормальним зором, як при сприйманні виразних засобів емоцій, так і при їхньому відтворенні.

Словесний опис і позначення різних емоцій, представлених дітям у серії малюнків (гнів, подив, страх, страждання, радість тощо) на підставі сприймання дітьми міміки показало, що у дітей з порушеннями зору є дуже нечіткі, недостатньо диференційовані уявлення про емоції, як інформативну характеристику стану людини в процесі комунікації.

Як наголошує Л. Григорьєва [4], формування зорового образу - це полісистемний процес, який охоплює аналіз сенсорних ознак об'єктів, віддзеркалює ïх взаємозв'язки й завершується семантичними перетвореннями. Тобто, іншими словами, формування зорових образів - це складна системна діяльність, яка

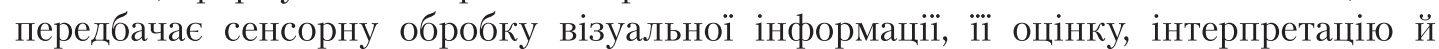
категоризацію.

Незалежно від того, який тип сприймання складається у слабозорої дитини, він володіє усіма властивостями, відомими у загальній психології: вибірковістю, осмисленістю, узагальненням, аперцепцією й константністю. Зрозуміло, прояв і розвиток цих властивостей залежить від того, в якому вигляді сприймання вони виявляються, а також - від рівня психічного розвитку дитини загалом. При слабозорості спостерігається редукованість проявів деяких властивостей сприймання. Так зокрема, вибірковість сприймання обмежується вузьким колом інтересів, меншим, у порівнянні з нормою, емоційним впливом об'єктів зовнішнього світу; аперцепція виявляється слабше, аніж у нормі, у зв'язку із недостатнім чуттєвим досвідом; осмислення та узагальнення образів ускладнюється недостатністю чуттєвого досвіду й зниженням їх повноти і точності; скорочується зона константного зорового сприймання [8].

Участь у перцептивному процесі декількох аналізаторних систем реалізується у їх спільній діяльності, як інтегративна діяльність аналізаторів, в результаті якої під впливом комплексних подразників утворюються тимчасові нервові зв'язки, що у кінцевому результаті становить фізіологічний механізм сприймання. Важливим також є те, що комплексна діяльність аналізаторів відбувається 
на основі взаємодії першої та другої сигнальних систем, завдяки чому людське сприймання принципово відрізняється від сприймання тварин своїм усвідомленням, узагальненням і довільністю.

Участь системи мовлення у побудові вищих психічних функцій становить їхню найважливішу рису. Саме в зв'язку із цим I. Павлов мав усі підстави вважати другу сигнальну систему, «клітиною» якої є слово, вищим регулятором людської поведінки [11].

Позначаючи предмет або його властивість, слово виділяє їх із навколишньої дійсності та вводить у певні зв'язки із іншими предметами чи ознаками. Той факт, що «слово узагальнює», має вирішальне значення у системному віддзеркаленні дійсності, у переході від відчуття до мислення, у створенні нових функціональних систем. Слово не тільки позначає предмети зовнішнього світу, а й виділяе іхні істотні властивості та вводить іх у систему відношень 3 іншими предметами. Завдяки наявності мови, дитина може викликати образ відповідного предмета і оперувати із ним за його відсутності. Водночас слово, вирізняючи істотні ознаки й узагальнюючи предмети, які воно позначає, дає можливість глибше проникати у навколишню дійсність. Усе це підносить психічні процеси на якісно новий рівень, створює можливість їхньої нової організації, дасть змогу дитині управляти психічними процесами [9].

Висновки. Підбиваючи підсумок теоретичного огляду питання, необхідно відзначити, що в сучасних дослідженнях у галузі тифлопсихології мовлення розглядається як найважливіша детермінанта компенсаторного розвитку і в цьому відношенні іiі функції реалізуються трьома шляхами: по- перше, - шляхом застосування мовлення як засобу спілкування й засвоєння суспільно виробленого досвіду, зафіксованого в слові; по-друге, - як засобу уточнення й закріплення безпосереднього чуттєвого досвіду; по-третє, - як засобу регуляції пізнавальних дій на звуженій сенсорній основі.

Уже сама соціальна генеза вищих психічних функцій, їхнє формування в процесі предметної діяльності та спілкуванні визначає іх опосередковану будову. Л. Виготський неодноразово зазначав, що розвиток психічних здібностей відбувається не за типом «еволюції за чистими лініями» (коли та або інша властивість поступово удосконалюється сама по собі), а за типом «еволюції за змішаними лініями», інакше кажучи, за типом створення нових, опосередкованих структур психічних процесів і нових міжфункціональних відношень, спрямованих на здійснення попередніх завдань новими засобами.

Співвідношення окремих компонентів, що входять до складу вищих психічних функцій, не залишається незмінним на послідовних етапах їхнього розвитку. На ранніх етапах відносно прості чуттєві процеси, що слугують фундаментом для розвитку вищих психічних функцій, відіграють вирішальну роль, однак на наступних етапах, коли вищі психічні функції вже сформувалися, ця провідна роль переходить до більш складних систем, утворених на мовленнєвій основі, які починають визначати усю будову вищих психічних процесів. Саме тому, порушення відносно елементарних процесів чуттєвого аналізу та синтезу в ранньо-

«ОСОБЛИВА ДИТИНА: навчання і виховання», № 4, 2019 
му дитинстві, викликає недорозвиток усіх функціональних утворень, які надбудовуються на їх основі.

\section{ЛITEPATУPA}

1. Ананъев Б. Г. Избранные психологические труды / Б. Г. Ананьев. - М., 1980. - 287 с. (Собр. Соч.: Т. 2).

2. Брунер Д. С. Психология познания / Д. С. Брунер - М., 1977. - С. 14-130.

3. Грегори Р. Л. Глаз и мозг: Психология зрительного восприятия / Р. Л.; Грегори [пер. с англ. Е.Д. Хомской]. - М.: Прогресс, 1970. - 271 с.

4. Григорвева Л. П. Формирование высших форм зрительного восприятия как основа компенсации нарушений когнитивного развития детей / Л. П. Григорьева // Дефектология. 2000. - № 1. - С. 3-15.

5. Кобильченко В. В. Психологічний супровід дітей дошкільного віку з порушеннями зору: монографія / В. В. Кобильченко. - Полтава: ТОВ «Фірма «Техсервіс», 2015. - 205 с.

6. Кобильченко B. В. Теоретичні основи психолого-педагогічного супроводу молодших школярів з порушеннями зору / В. В. Кобильченко. - Полтава: ТОВ «Фірма «Техсервіс», 2017. $-367 \mathrm{c}$.

7. Кобыльченко В. В Становление личности дошкольника в норме и при нарушениях зрения: монография / В. В. Кобыльченко.. Saarbr cken: LAP LAMBERT Academic Publishing, 2015. $540 \mathrm{c}$.

8. Литвак А. Г. Тифлопсихология / А. Г. Литвак. - М., Просвещение, 1985. - 206 с.

9. Лурия А. Р. Высшие корковые функции человека и их нарушение при локальных поражениях мозга / А. Р. Лурия - М.: Изд-во АПН РСФСР, 1969. - 504 с.

10. Моргулис И. С. Организация коррекционно-воспитательного процесса в школе слепых / И. С. Моргулис - К., 1991. - Ч. І. - 112 с.

11. Павлов И. П. Полн. собр. соч. / И. П. Павлов - М.:Л., 1951. - 257 с. - (Т. III. - Кн. 2.).

12. Сеченов И. М. Избранные философские и психологические произведения / И.М. Сеченов - М, 1947. - С. 394-397.

13. Синвова $С$. П. Особливості розвитку та виховання особистості при глибоких порушеннях зору: монографія / Є. П. Синьова. - К.: НПУ імені М. П. Драгоманова, 2012. - 442 с.

14. Солнцева Л. И. Введение в тифлопсихологию раннего, дошкольного и школьного возраста / Л. И. Солнцева - М.: Полиграфсервис, 1997. - 124 с.

\section{REFERENCES (TRANSLATED AND TRANSLITERATED)}

1. Anan'ev B. G. (1980). Izbrannye psihologicheskie trudy. M. [In Russian].

2. Bruner D. S. (1977). Psihologija poznanija. M. [In Russian].

3. Gregori R. L. (1970). Glaz i mozg: Psihologija zritel'nogo vosprijatija. M.: Progress. [In Russian].

4. Grigor'eva L. P. (2000). Formirovanie vysshih form zritel'nogo vosprijatija kak osnova kompensacii narushenij kognitivnogo razvitija detej. Defektologija. 1. [In Russian].

5. Kobylchenko V. V. (2015). Psykholohichnyi suprovid ditei doshkilnoho viku z porushenniamy zoru: monohrafiia. Poltava: TOV «Firma «Tekhservis». [In Ukrainian].

6. Kobylchenko V. V. (2017). Teoretychni osnovy psykholoho-pedahohichnoho suprovodu molodshykh shkoliariv z porushenniamy zoru. Poltava: TOV «Firma «Tekhservis». [In Ukrainian]. 
7. Kobylchenko V.V (2015). Stanovlenie lichnosti doshkol'nika v norme i pri narushenijah zrenija. Saarbr cken: LAP LAMBERT Academic Publishing. [In Russian].

8. Litvak A. G. (1985). Tiflopsihologija. M. : Prosveshhenie. [In Russian].

9. Lurija A. R. (1969). Vysshie korkovye funkcii cheloveka i ih narushenie pri lokal'nyh porazhenijah mozga. M.: Izd-vo APN RSFSR. [In Russian].

10. Morgulis I. S. (1991). Organizacija korrekcionno-vospitatel'nogo processa v shkole slepyh. K. [In Russian].

11. Pavlov I. P. (1951). Poln. sobr. soch. M. [In Russian].

12. Sechenov I. M. (1947). Izbrannye filosofskie i psihologicheskie proizvedenija. M. [In Russian].

13. Synova Ye. P. (2012). Osoblyvosti rozvytku ta vykhovannia osobystosti pry hlybokykh porushenniakh zoru: monohrafiia. K.: NPU imeni M.P. Drahomanova. [In Ukrainian].

14. Solnceva L. I. (1997). Vvedenie v tiflopsihologiju rannego, doshkol'nogo i shkol'nogo vozrasta. M.: Poligrafservis. [In Russian]. 